\title{
The scientific basis for new and sustainable management of migratory European ducks
}

Author(s): Johan Elmberg, Petri Nummi, Hannu Pöysä, Kjell Sjöberg, Gunnar Gunnarsson, Preben Clausen, Matthieu Guillemain, David Rodrigues, and Veli-Matti Väänänen

Source: Wildlife Biology, 12(2):121-127.

Published By: Nordic Board for Wildlife Research

https://doi.org/10.2981/0909-6396(2006)12[121:TSBFNA]2.0.CO;2

URL: http://www.bioone.org/doi/full/10.2981/0909-6396\%282006\%2912\%5B121\%3ATSBFNA $\% 5 \mathrm{D} 2.0 . \mathrm{CO} \% 3 \mathrm{~B} 2$

BioOne (www.bioone.org) is a nonprofit, online aggregation of core research in the biological, ecological, and environmental sciences. BioOne provides a sustainable online platform for over 170 journals and books published by nonprofit societies, associations, museums, institutions, and presses.

Your use of this PDF, the BioOne Web site, and all posted and associated content indicates your acceptance of BioOne's Terms of Use, available at www.bioone.org/page/terms_of_use.

Usage of BioOne content is strictly limited to personal, educational, and non-commercial use. Commercial inquiries or rights and permissions requests should be directed to the individual publisher as copyright holder. 


\title{
The scientific basis for new and sustainable management of migratory European ducks
}

\author{
Johan Elmberg, Petri Nummi, Hannu Pöysä, Kjell Sjöberg, Gunnar Gunnarsson, Preben Clausen, \\ Matthieu Guillemain, David Rodrigues \& Veli-Matti Väänänen
}

Elmberg, J., Nummi, P., Pöysä, H., Sjöberg, K., Gunnarsson, G., Clausen, P., Guillemain, M., Rodrigues, D. \& Väänänen, V-M. 2006: The scientific basis for new and sustainable management of migratory European ducks. - Wildl. Biol. 12: 121-127.

It is an axiom in ecology that knowing the sheer number of individuals in a population is of very little help if the objective is to understand future and past changes in population size. Yet, this is exactly how migratory European ducks are monitored, many of which are important quarry species in several countries. We argue that present monitoring is insufficient to address objectives of wise use and sustainability such as those emphasised in recent management directives and multilateral international agreements. The two main problems are the almost total lack of reliable data on recruitment and mortality. We advocate a pan-European monitoring system based on undisputed scientific principles; i.e. a long-term, coordinated and standardised scheme that produces data about vital rates of duck populations as well as about harvest size. Data from such a scheme can be used by game biologists to produce predictive tools, thus providing a functional basis for management decisions for adaptive harvesting and conservation alike.

Key words: duck, management, monitoring, population, policy, sustainability, waterfowl

Johan Elmberg, Department of Mathematics and Natural Sciences, Kristianstad University, SE-291 88, Kristianstad, Sweden-e-mail: Johan.Elmberg@mna. hkr.se

Petri Nummi \& Veli-Matti Väänänen, Department of Applied Biology, University of Helsinki, P.O. Box 27, FIN-00014, University of Helsinki, Finland-e-mail addresses: petri.nummi@helsinki.fi (Petri Nummi); veli-matti.vaananen@ helsinki.fi (Veli-Matti Väänänen)

Hannu Pöysä, Finnish Game and Fisheries Research Institute, Joensuu Game and Fisheries Research, Yliopistokatu 6, FIN-80100, Joensuu, Finland-e-mail: hannu.poysa@rktl.fi

Kjell Sjöberg, Department of Animal Ecology, Swedish University of Agricultural Sciences, SE-901 83,Umeå, Sweden-e-mail: kjell.sjoberg@szooek.slu.se Gunnar Gunnarsson, Department of Mathematics and Natural Sciences, Kristianstad University, SE-291 88, Kristianstad, Sweden and Department of Animal Ecology, Swedish University of Agricultural Sciences, SE-901 83, Umeå, Sweden-e-mail: gunnar.gunnarsson@mna.hkr.se

Preben Clausen, National Environmental Research Institute, Department of Wildlife Ecology and Biodiversity, Grenåvej 14, DK-8410 Rфnde, Denmark - e-mail: $p c @ d m u . d k$ 
Matthieu Guillemain, Office National de la Chasse et de la Faune Sauvage, CNERA Avifaune Migratrice, La Tour du Valat, Le Sambuc, F-13200 Arles, France-e-mail:m.guillemain@oncfs.gouv.fr

David Rodrigues, Forest Department, Agronomics High School of Coimbra, ESAC, Bencanta, PT-3040-316Coimbra,Portugal-e-mail:drodrigues@mail. esac.pt

Corresponding author: Johan Elmberg

Received 31 December 2004, accepted 25 July 2005

Associate Editor: John W. Connelly

"Furthermore, there is a need for sound, scientifically based monitoring mechanisms to ensure that any use is maintained at levels which can be sustained by the wild populations without adversely affecting the species' role in the ecosystem or the ecosystem itself."

"The availability of good quality scientific information on population size and natural mortality is a prerequisite of reliable calculations."

Quotes from sections 2.4.16 and 3.5.38 in 'the Guidance document on hunting under Council Directive 79/409/ EEC on the conservation of wild birds' by the European Commission.

\section{Understanding population change}

Basic population ecology emphasises that knowing population size alone is of rather limited help to those who want to forecast changes in numbers or understand the processes behind past variations. Another fundamental point is that population change depends on the combined effects of natality, mortality, immigration and emigration, and that these factors need to be expressed on a per capita basis. These so called vital rates are often age-, sex- and site-specific (e.g. Krebs 2001, Townsend et al. 2003). Based on a large body of evidence, it is also generally acknowledged that vital rates may vary with population density (Newton 1998). If density-dependent processes produce such patterns, population size may change in a non-linear and even counter-intuitive fashion (Royama 1992).

In other words, variation in vital rates and densitydependent processes both make it essential to document age structure, sex ratio and density of wild populations under study. Without such data it is impossible to understand population change and to forecast population size, even if environments were stable. However, environments do change, for natural as well as for anthropogenic reasons, generating variation in critical factors such as weather, habitat area and food abundance (GossCustard et al. 1994, Sutherland 1996, 1998).

Harvested species are especially relevant examples in this context, as density dependence in one or more vital rates is a prerequisite for harvest mortality to be compensatory instead of additive to natural mortality (Anderson \& Burnham 1976, Burnham \& Anderson 1984, Sæther et al. 1996, Boyce et al. 1999, Kokko 2001). Further, the timing of harvest in relation to naturally occurring density-dependent processes is critical to future population size and consequently to what can be considered a sustainable harvest level (Kokko et al. 1998). Recent decades provide ample examples of this predicament, for example in marine fisheries and hunting regulations (Buckworth 2001, Pitcher \& Pauly 2001, Myers \& Worm 2003, Sheaffer et al. 2004).

\section{Importance of European duck populations}

Waterfowl, i.e. swans, geese and ducks, are flagship birds in wetland research and in conservation worldwide, being widely appreciated and well known by the public. They are also an integral part of wetland ecosystems, with many species ranking high in importance as hunted game. The latter is true throughout the Holarctic, with hunters in the present European Union probably numbering close to 10 million ( $c f$. Lecocq 1993).

Harvested migratory species present a particular challenge when it comes to understanding population dynamics. Most European ducks are migratory, and many species have their wintering areas in the western and southern parts of the continent, while breeding generally takes place in the north and the east (Scott \& Rose 1996). It is evident from recent analyses of ringing recoveries (Fransson \& Pettersson 2001, Wernham et al. 2002, Bakken et al. 2003) that 'the average species' utilises sever- 
al countries during its annual cycle, which is why studying as well as managing European ducks becomes a multi-lateral endeavour.

Hence, knowing the sheer numbers of the different species really does not do the job when it comes to forecasting population change or to devising sustainable management strategies. Yet, this is the basic idea of most duck monitoring in Europe, and, with the exception of some threatened species (e.g. Green \& Anstey 1992, Green 1993, Petkov et al. 2003), this is the type of data on which present policies for conservation, hunting and habitat management are deemed to be based.

\section{Limitations of present monitoring}

No one knows exactly how many birdwatchers, hunters and other volunteers are involved in the present activities for monitoring European ducks, but we expect it to be a five-digit number ( $c f$. Gilissen et al. 2002). Large sums of money are spent on this purpose annually, by volunteers and by the bodies co-ordinating and compiling the data. For the ONCFS alone, one of several participating organisations in the French winter counts, the yearly cost is probably more than $120.000 €$. What, then, do the results from this huge effort tell scientists and managers about variation in vital rates and other critical parameters?

Unfortunately, the data do not provide much insight into this variation. We acknowledge that the monitoring schemes taken together indeed have and do generate useful data for the conservation of waterfowl and their habitats (e.g. Scott \& Rose 1996, Delany \& Scott 2002, Gilissen et al. 2002). However, the data obtained are utterly insufficient to achieve the objectives of wise use and sustainability in present national and multinational (e.g. EU) policies. This is because too little information of the type needed to understand and to forecast population change is produced.

Most European monitoring data are and have always been collected outside the breeding season. In addition, the vast majority of the long-term records originate from only a few densely populated regions in Western Europe, where birds, volunteers and money occur together. Major problems with this type of information include the following:

- Generally no data are collected about age-class distribution and its variation within as well as between years. Hence, there are no estimates of recruitment.

- Even if attempted, measuring recruitment on wintering grounds is practically impossible because an unknown share of the mortality, natural as well as harvest, occurs before the birds get there.
- Local and national changes in 'population size' may be due to altered behaviour locally and can depend on to what extent non-monitored areas are utilised.

- Observed 'stable numbers' may result from increased recruitment from one breeding area compensating for a potentially noteworthy decrease in another.

- The spatial distribution of ducks in a given winter may depend to a large extent on weather conditions; i.e. an unknown fraction of the population may remain outside the monitored area in some years, especially in mild winters.

We argue that the present monitoring activities are largely suboptimal for most species in terms of time, energy and money spent, especially when considered at a continental or flyway level. Some birds are counted several times, but in different countries, and some birds do not get counted at all. Moreover, most effort goes into counting live birds. A few European countries have bag statistics providing annual and fairly reliable indices of harvest levels for many species (Sweden starting 1939 and ongoing, Kindberg 2003; Denmark since 1941 and ongoing, Strandgaard \& Asferg 1980, Asferg 2004; Finland since 1962 and ongoing, Official Statistics of Finland 2004). In most countries national bag statistics are, however, collected with long intervals, not at all, or in a way that does not provide a reliable measure of harvest size ( $c f$. Harradine 1985, Landry 1990, Nichols et al. 2001). This means there are no reliable data about annual hunting harvests for most species, at least at population and flyway levels, and notably not from countries where most ducks winter and where wildfowlers are numerous.

Present monitoring schemes thus produce data restricting scientists and managers to retrospective and correlative approaches of what may have happened and why. Put another way, the wealth of reports and papers produced about duck numbers in Europe does not provide the information needed to devise predictive tools. Consequently, most decisions about management are based on insufficient data, largely untested assumptions, or even guesses. Examples of decisions based on potentially very poor knowledge are those concerning bag limits, duration of the hunting season, the relative value of specific wetlands, and perhaps even the classification of international conservation status of species.

Management policies are increasingly being based on the idea that harvesting should be sustainable, i.e. that the kill and the natural mortality together must not exceed the recruitment. This can never be ensured as long as neither recruitment nor harvest is measured. Wetlands International and other NGOs frequently state that sus- 
tainability is a key issue in management. The idea of sustainability is also widely recognised and accepted by governments and in multi-lateral international agreements. Although the concept is not specifically mentioned in the EEC Birds Directive (Council Directive 79/409/EEC on the conservation of wild birds), EU member states "shall ensure that the practice of hunting, including falconry if practised, as carried on in accordance with the national measures in force, complies with the principles of wise use and ecologically balanced control of the species of birds concerned" (quote from article 7.4). Further, parties to the agreement on the conservation of AfricanEuroasian Migratory Waterbirds (AEWA) must "ensure that any use of migratory waterbirds is based on an assessment of the best available knowledge of their ecology and is sustainable for the species as well as for the ecological systems that support them" (quote from Article III).

As we have already argued, implementing sustainability presumes some kind of forecasting, and the only way is through predictive models (e.g. Johnson et al. 1997). Reliable monitoring of recruitment, population sizes, survival and harvest rates is a minimum requirement for the adjustment of harvest regulations to long-term population changes (Sutherland 2001, Johnson et al. 2002). A truly adaptive management may even require that harvest can be 'fine-tuned' to population size on an annual basis.

\section{Desiderata for a sustainable management}

The study by Frederiksen et al. (2004) clearly points out that it is insufficient to count waterfowl and to assess recruitment by scoring juvenile proportions in the wintering area alone. This approach simply does not produce the relevant information and the data quality needed for decisions in management, harvesting and policymaking. Since population change depends on the combined effects of natality, mortality, immigration and emigration, all four parameters should be targeted in a comprehensive monitoring scheme.

A much needed start would be to regularly produce estimates of the breeding population size and reproductive output of European ducks. This may be straightforward in some species, but for most it will be necessary to conduct stratified large-scale surveys in the breeding areas. Such surveys must represent different parts of the range of a species as well as breeding habitats of potentially different quality. In some regions pair and brood counts can probably be carried out from low-flying aircraft ( $c f$. Haapanen \& Nilsson 1979), as has been done in North America for $>50$ years (Brasher et al. 2002). The vast areas of lake-dotted taiga and subarctic wetlands in Russia and Fennoscandia are especially suited for this approach, as there are few local ornithologists and severe logistic challenges for ground-based work. However, all aerial data will need ground verification on a regular basis so that results can be converted to 'real ducks' and subsequently to indices of per capita birth rate and recruitment. Although there are already a few nation-wide programmes approaching such ambitions (e.g. Pöysä et al. 1993, Musil et al. 2001), we are not aware of any multi-lateral effort in Europe concerning the more widespread and commonly harvested species. As already implied, it is essential that estimates of population size and recruitment be made before fall migration starts and before any harvesting occurs.

Mortality should be assessed along migration routes as well as in wintering areas. Existing historical ringingrecovery data can be used as a supplement to address aspects of mortality and site fidelity. In North America there is a long and successful tradition of such work (e.g. Krements et al.1997, Doherty et al. 2002). Corresponding databases in the European countries remain largely unexplored, though some exceptions do exist (Dow \& Fredga 1983, Hario \& Selin 1988, Blums et al. 1996, Pradel et al. 1997, Milonoff et al. 1998, Ruusila et al. 2000, Blums et al. 2002).

Obtaining more reliable information on hunting bags is also a central issue so that mortality patterns are understood in a spatial and temporal context, and the relative importance of hunting mortality in relation to natural mortality is documented. By combining bag statistics with collecting wings from hunted species (as practised in Denmark since 1966; Joensen 1978, Bregnballe et al. 2003, Clausager 2004, cf. Geissler 1990 and Pendleton 1992), valuable knowledge about the timing of the harvest as well as age- and sex-specific hunting mortality in populations can be obtained. This is especially true for wing samples from the breeding areas, i.e. from birds shot in late summer and early fall before the subpopulations start mixing.

A reformed European monitoring programme for ducks should be executed in a standardised multinational fashion and with a long-term perspective. Rather than attempting to count ducks everywhere, sampling must embrace areas representing different population densities, different geographical areas as well as habitat types of different quality and stability. By doing so, monitoring may serve dual purposes by also creating synergies with game scientists, as practice and theory need to go hand in hand (Pöysä et al. 2004). For example, correlative patterns emerging from a new monitoring approach can serve as a valuable basis for experimental research addressing the causality underlying variations in birth 
and death rates, including density-dependent processes (Newton 2004, Elmberg et al. 2005). Such studies may include local manipulations of population density, exclosure of foraging habitats to address food resource limitation, artificially increased food abundance and aspects of mortality. The latter may be accomplished by temporary modifications of harvest regimes.

\section{Implications and prospects}

We are not saying that the present monitoring activities of wintering ducks in Western Europe should be suspended. As we have already mentioned, they have produced, and certainly will produce, useful data for the conservation of waterfowl and their winter habitats. However, they should be supplemented and carefully reformed or replaced by a new monitoring system that can provide the necessary information for a scientifically based sustainable management of European ducks. We also call for a system that will allow adaptive management, i.e. adjustment of harvest levels to annual variations in population size and breeding success. If the necessity of monitoring breeding populations is acknowledged, resources need to be diverted to the breeding habitats. For some species this means the boreal and arctic wetlands of Fennoscandia and Russia, but for others ponds, lakes and wetlands throughout Europe would be involved.

As is evident from the quotes in this paper, there is already some official awareness of what type of knowledge the future management of European ducks should rely on. What political and organisational measures need to be taken in order to really achieve these goals is not a scientific issue, but the pressing responsibility of politicians, government agencies, the EU and NGOs involved in waterfowl and wetlands. As European ducks are a truly multinational resource, a high degree of international cooperation and coordination is needed.

Acknowledgements - John W. Connelly and James Sedinger kindly provided constructive criticism on an earlier draft.

\section{References}

Anderson, D.R. \& Burnham, K.P. 1976: Population ecology of the mallard. VI. The effect of exploitation on survival. United States Department of the Interior, Fish and Wildlife Service Resource Publication 128, 66 pp.

Asferg, T. 2004: Vildtudbyttet i Danmark i jagtsæsonen 2002/2003. - National Environmental Research Institute, Technical Report 491, Kalø, Denmark, 24 pp. (In Danish). Available at: http://www2.dmu.dk/1_viden/2_Publikationer/ 3_fagrapporter/rapporter/FR491.PDF.

Bakken, V., Runde, O. \& Tjørve, E. 2003: Norsk ringmerkings- atlas. Vol.1. Lommer - Alkefugler. - Norwegian Bird Ringing Atlas, Stavanger Museum, Stavanger, 431 pp. (In Norwegian with English summaries).

Blums, P., Mednis, A., Bauga, I., Nichols, J.D. \& Hines, J.E. 1996: Age specific survival and philopatry in three species of European ducks: a long-term study. - Condor 98: 61-74.

Blums, P., Nichols, J.D., Hines, J.E. \& Mednis, A. 2002: Sources of variation in survival and breeding site fidelity in three species of European ducks. - Journal of Animal Ecology 71: 438-450.

Boyce, M.S., Sinclair, A.R.E. \& White, G.C. 1999: Seasonal compensation of predation and harvesting. - Oikos 87: 419426.

Brasher, M.G., Kaminski, R.M. \& Rurger, L.W. 2002: Evaluation of indicated breeding pair criteria to estimate mallard breeding populations. - Journal of Wildlife Management 66: 985-992.

Bregnballe, T., Asferg, T., Clausager, I., Noer, H., Clausen, P. \& Christensen, T.K. 2003: Vildtbestande, jagt og jagttider i Danmark 2002. En biologisk vurdering af jagtens bæredygtighed som grundlag for jagttidsrevisionen 2003. - National Environmental Research Institute Technical Report 428, Kalø, Denmark, 227 pp. (In Danish). Available at: http:// www2.dmu.dk/1_viden/2_Publikationer/3_fagrapporter/ rapporter/FR428.PDF.

Buckworth, R.C. 2001: World fisheries are in crisis? We must respond! - In: Pitcher, T.J., Hart, P.J.B. \& Pauly, D. (Eds.); Reinventing fisheries management. Kluwer Academic Publishers, Dordrecht, pp. 3-17.

Burnham, K.P. \& Anderson, D.R. 1984: Tests of compensatory vs. additive hypotheses of mortality in mallards. - Ecology 65: 105-112.

Clausager, I. 2004: Vingeindsamling fra jagtsæsonen 2003/04 i Danmark. Wing survey from the 2003/04 hunting season in Denmark. - National Environmental Research Institute, Technical Report 504, Kalø, Denmark, 70 pp. (In Danish with an English summary). Available at: http://www2.dmu. dk/1_viden/2_Publikationer/3_fagrapporter/rapporter/ FR504.PDF.

Delany, S. \& Scott, D. (Eds.) 2002: Waterbird population estimates. 3rd edition. - Wetlands International Global Series No. 12, Wageningen, the Netherlands, 226 pp.

Doherty, P.F., Nichols, J.D., Tautin, J., Voelzer, J.F., Smith, G.W., Benning, D.S., Bentley, V.R., Bidwell, J.K., Bollinger, K.S., Brazda, A.R., Buelna, E.K., Goldsberry, J.R., King, R.J., Roetker, F.H., Solberg, J.W., Thorpe, P.P. \& Wortham, J.S. 2002: Sources of variation in breeding-ground fidelity of mallards (Anas platyrhynchos). - Behavioural Ecology 13: 543-550.

Dow, H. \& Fredga, S. 1983: Breeding and natal dispersal of the goldeneye, Bucephala clangula. - Journal of Animal Ecology 52: 681-696.

Elmberg, J., Gunnarsson, G., Pöysä, H., Sjöberg, K. \& Nummi, P. 2005: Within-season sequential density dependence regulates breeding success in Mallards Anas platyrhynchos. Oikos 108: 582-590.

Fransson, T. \& Pettersson, J. 2001: Svensk ringmärkningsat- 
las. Vol 1. - Swedish bird ringing atlas, Swedish National Museum of Natural History, Stockholm, 190 pp. (In Swedish with English summaries).

Frederiksen, M., Hearn, R.D., Mitchell, C., Sigfusson, A., Swann, R.L. \& Fox, A.D. 2004: The dynamics of hunted Icelandic goose populations: a reassessment of the evidence. Journal of Applied Ecology 41: 315-334.

Geissler, P.H. 1990: Estimation of confidence intervals for federal waterfowl harvest surveys. - Journal of Wildlife Management 54: 201-205.

Gilissen, N., Haanstra, L., Delany, S., Boere, G. \& Hagemeijer, W. 2002: Numbers and distribution of wintering waterbirds in the Western Palearctic and Southwest Asia in 1997, 1998 and 1999. - Wetlands International, Global Series 11, Wageningen, the Netherlands, $182 \mathrm{pp}$.

Goss-Custard, J.D., Caldow, R.W.G., Clarke, R.T., le V. dit Durell, S.E.A., Urfi, J. \& West, A.D. 1994: Consequences of habitat loss and change to populations of wintering migratory birds: predicting the local and global effects from studies of individuals. - Ibis 137: S56-S66.

Green, A.J. 1993: The status and conservation of the marbled teal Marmaronetta angustirostris. - IWRB Special Publication 23, Slimbridge, UK, 108 pp.

Green, A.J. \& Anstey, S. 1992: The status of the white-headed duck (Oxyura leucocephala). - Bird Conservation International 2: 185-200.

Haapanen, A. \& Nilsson, L. 1979: Breeding waterfowl populations in northern Fennoscandia. - Ornis Scandinavica 10: 145-219.

Hario, M. \& Selin, K. 1988: Thirty-year trends in an eider population: timing of breeding, clutch size, and nest site preferences. - Finnish Game Research 45: 3-10.

Harradine, J. 1985: Duck shooting in the United Kingdom. Wildfowl 36: 81-94

Joensen, A.H. 1978: Statistics of duck hunting in Denmark 1966-1976. - Danish Review of Game Biology 10: 1-20.

Johnson, F.A., Kendall, W.L. \& Dubovsky, J.A. 2002: Conditions and limitations on learning in the adaptive management of mallard harvests. - Wildlife Society Bulletin 30: 176-185.

Johnson, F.A., Moore, C.T., Kendall, W.L., Dubovsky, J.A., Caithamer, D.F., Kelley, J.R., Jr. \& Williams, B.K. 1997: Uncertainty and the management of mallard harvests. - Journal of Wildlife Management 61: 202-216.

Kindberg, J. 2003: Viltövervakningen. Årsrapport 2002. - Svenska Jägareförbundets viltövervakning, 7 pp. (In Swedish).

Kokko, H. 2001: Optimal and suboptimal use of compensatory responses to harvesting: timing of hunting as an example. - Wildlife Biology 7: 141-150.

Kokko, H., Pöysä, H., Lindström, J. \& Ranta, E. 1998: Assessing the impact of spring hunting on waterfowl populations. - Annales Zoologici Fennici 35: 195-204.

Krebs, C. 2001: Ecology. 5th edition. - Benjamin Cummings, San Francisco, 695 pp.

Krements, D.G., Barker, R.J. \& Nichols, J.D. 1997: Sources of variation in waterfowl survival rates. - Auk 114: 93-102.

Landry, P. 1990: Bag statistics: a review of methods and prob- lems. - In: Matthews, G.W.T. (Ed.); Managing Waterfowl Populations. Proceedings of an IWRB Symposium, Astrakhan, USSR 1989, IWRB Special Publication No. 12, Slimbridge, pp. 105-112.

Lecocq, Y. 1993: Wise use of waterfowl: a European perspective. - In: Moser, M., Prentice, R.C. \& van Vessem, J. (Eds.); Waterfowl and wetland conservation in the 1990s. A global perspective. Proceedings of an IWRB Symposium, St Petersburg Beach, Florida, USA, 12-bureau, IWRB Special Publication No. 26, pp. 87-89.

Milonoff, M., Pöysä, H. \& Runko, P. 1998: Factors affecting clutch size and duckling survival in the common goldeneye Bucephala clangula. - Wildlife Biology 4: 73-80.

Musil, P., Cepák, J., Hudec, K. \& Zárybnický, J. 2001: The long-term trends in the breeding waterfowl populations in the Czech Republic. - OMPO \& Institute of Applied Ecology, Kostelec nad Černými lesy, PB tisk, Př́ibram, Czech Republic, $120 \mathrm{pp}$.

Myers, R.A. \& Worm, B. 2003: Rapid worldwide depletion of predatory fish communities. - Nature 423: 280-283.

Newton, I. 1998: Population limitation in birds. - Academic Press, San Diego, 597 pp.

Newton, I. 2004: Population limitation in migrants. - Ibis 146: 197-226.

Nichols, J.D., Lancia, R.A. \& Lebreton, J-D. 2001: Hunting statistics: what data for what use? An account of an international workshop. - Game and Wildlife Science 18: 185205.

Official Statistics of Finland 2004: Annual game bag 2003. Official Statistics of Finland 2004: 58. Finnish Game and Fisheries Research Institute, Helsinki, 25 pp.

Pendleton, G.W. 1992: Nonresponse patterns in the federal waterfowl hunter questionnaire survey. - Journal of Wildlife Management 56: 344-348.

Petkov, N., Hughes, B. \& Gallo-Orsi, U. (Eds.) 2003: Ferruginous duck: From research to conservation. - Conservation Series No 6, BirdLife International - BSPB - TWSG, Sofia, 144 pp.

Pitcher, T.J. \& Pauly, D. 2001: Rebuilding ecosystems, not sustainability, as the proper goal of fishery management. In: Pitcher, T.J., Hart, P.J.B. \& Pauly, D. (Eds.); Reinventing fisheries management. Kluwer Academic Publishers, Dordrecht, pp. 311-329.

Pradel, R., Rioux, N., Tamisier, A. \& Lebreton, J-D. 1997: Individual turnover among wintering Teal in Camargue: a markrecapture study. - Journal of Wildlife management 61: 816821.

Pöysä, H., Elmberg, J., Gunnarsson, G., Nummi, P. \& Sjöberg, K. 2004: Ecological basis of sustainable harvesting: is the prevailing paradigm of compensatory mortality still valid? - Oikos 104: 612-615.

Pöysä, H., Lammi, E., Väisänen, R.A. \& Wikman, M. 1993: Monitoring of waterbirds in the breeding season: the programme used in Finland in 1986-92. - In: Moser, M., Prentice, R.C. \& van Vessem, J. (Eds.); Waterfowl and wetland conservation in the 1990s. A global perspective. Proceedings of an IWRB Symposium, St Petersburg Beach, Florida, 
USA, 12-bureau, IWRB Special Publication No. 26, pp. 712.

Royama, T. 1992: Analytical population dynamics. - Chapman \& Hall, London, 371 pp.

Ruusila, V., Pöysä, H. \& Runko, P. 2000: Characteristics of maternal family lineages in a common goldeneye Bucephala clangula breeding population. - Ornis Fennica 77: 77-82.

Sæther, B-E., Engen, S. \& Lande, R. 1996: Density-dependence and optimal harvesting of fluctuating populations. Oikos 76: 40-46.

Scott, D.A. \& Rose, P.M. 1996: Atlas of Anatidae Populations in Africa and Western Eurasia. - Wetlands International Publication No. 41, Wetlands International, Wageningen, The Netherlands, 336 pp.

Sheaffer, S.E., Rusch, D.H., Humburg, D.D., Lawrence, J.S., Zenner, G.G., Gillespie, M.M., Caswell, F.D., Wilds, S. \& Yaich, S.C. 2004: Survival, movements, and harvest of Eastern Prairie population Canada Geese. - Wildlife Monographs $156,54 \mathrm{pp}$.
Strandgaard, H. \& Asferg, T. 1980: The Danish bag record II. Fluctuations and trends in the game bag record in the years 1941-1976 and the geographical distribution of the bag in 1976. - Danish Review of Game Biology 11: 1-112.

Sutherland, W.J. 1996: Predicting the consequences of habitat loss for migratory populations. - Proceedings of the Royal Society, B, 263: 1325-1327.

Sutherland, W.J. 1998: The effect of local change in habitat quality on populations of migratory species. - Journal of Applied Ecology 35: 418-421.

Sutherland, W.J. 2001: Sustainable exploitation: a review of principles and methods. - Wildlife Biology 7: 131-140.

Townsend, C.R., Begon, M. \& Harper, J.L. 2003: Essentials of ecology. 2nd edition. - Blackwell Publishing, Oxford, England, $530 \mathrm{pp}$.

Wernham, C.V., Toms, M.P., Marchant, J.H., Clark, J.A., Siriwardena, G.M. \& Baillie, S.R. 2002: The Migration Atlas: movements of the birds of Britain and Ireland. - T. \& A.D. Poyser, London, 720 pp. 